\title{
Recent Trends of International Migration and Remittance Flows: An Empirical Evidence of Bangladesh.
}

\author{
Masum Miah, Md. Abdul Mannan Khan, Mostafizur Rahman \\ ${ }^{I}$ (Lecturer, Department of Business Administration, Noakhali Science and Technology University, Bangladesh) \\ ${ }^{2}$ (Lecturer, Department of Accounting and Information Systems, Bangabandhu Sheikh Mujibur Rahman Science \\ and Technology University, Bangladesh) \\ ${ }^{3}$ (Lecturer, Department of Management, Bangabandhu Sheikh Mujibur Rahman Science and Technology \\ University, Bangladesh)
}

\begin{abstract}
International migration is considered to be an important livelihood strategy for the people of Bangladesh. This paper investigates natures and trends of migration and remittance flows of Bangladesh in the last years considering FY 2001-2002 to FY 2012-2013. This is an exploratory type of research based on secondary data generated from various reports of government and non-government organizations and of various publication of home and abroad. It is found that from FY2001-2002 to FY 2007-08 both the migration and remittance flows show an increasing trend but after this period it is showed a decreasing trend. The current research paper has identified various reasons behind this. Study also identifies that about 70 percent of total exports are in different countries of Middle East and most of the remittance also come from Middle East. It is also observed that $t$ due to different reason, the opportunity of manpower export to Middle East region is reducing. Therefore, for increasing the reserve as well as boosting up economic development through remittance flow, government of Bangladesh should come forward to search new scopes of manpower export.
\end{abstract}

Key Words: Bangladesh, Government, International Migration, Migration, Remittance.

\section{Introduction}

Human migration is the movement of people from one place to another for purposes of permanent or temporary residence and/or employment. In general, human migration has occurred throughout history and began with the movements of the first human groups out of their origins in East Africa (Tigno, 2006). Migration is complex, it flows are dynamic and constantly changing, the many different types and contexts of migration make it difficult to make satisfying theories and generalizations (Zeitlyn, 2006).In general there are two forms of migration. First one is internal and the other one is international. However, international migration has an extensive global phenomenon.

Bangladesh has a long history of migration and overseas remittances. Each year a large number of people of this country voluntarily migrate overseas for both long- and short-term employment (Siddiqui, 2005). Mahmood (1991) reported that as far back as in 1942 Bangladeshi nationals had migrated to the port cities of London and Liverpool in the UK. It is believed that thousands of Bangladeshis, especially from Sylhet, took the opportunity and created a flow of migration towards UK. For certain reasons, however, this flow had weakened by the 1960s and the direction of the migration flow changed in the 1970s. After the liberation war, most of the Bangladeshi sought to look job to Middle East countries as well as selected EU destinations (mainly Germany). Increase in oil price in 1970s opened up vast scope for Bangladeshi migrants in the Middle East which was later on expanded to the newly industrialized countries of South East Asia (Siddiqui, 2003). There was also a tendency to find employment in developed countries like USA, Canada, and Italy and in some Asian countries like Japan, Malaysia and Singapore in the 1990s and onward (Siddiqui, 2003).

However, migration has long been an important livelihood strategy for the people involved in this process, especially for the migrant people of developing and least developed countries (Siddiqui, 2003). Overseas migration not only produces large inflows of valuable remittances but also offers an outlet for frustrated unemployed workers. It is also important in order to reduce unemployment at home and accumulate valuable foreign exchange to stimulate economic growth (Hadi, 1999). With the passage of time international migration became part of the economic, social and political fabric of the country.

In Bangladesh, remittance is now the single largest source of foreign exchange earnings. It also plays a crucial role in alleviating the foreign exchange constraints and supporting the balance of payments, enabling imports of capital goods and materials for industrial development. It is a more stable and less volatile source of external finance when compared to the other forms of flows like as official development assistance and foreign direct investment (Ratha, 2007). At the micro level, it is also observed that remittances contribute towards increasing the income of receiving households with concomitant effects on the standard of living (Ratha, 2005). However, flow of workers' remittances in Bangladesh exhibited a continuously increasing trend over the last 30 
years in both absolute and relative terms. While total remittances to Bangladesh was only USD 24 million in 1976, the amount stood at USD14461.15million in 2013( Bangladesh bank, 2013). Bangladesh was the $7^{\mathrm{TH}}$ largest recipient of remittances among all of the remittance-recipient countries and $2^{\text {nd }}$ among all South Asian countries in terms of the amount of remittances received in 2011(Bangladesh Bank, 2011).

A number of studies have been conducted on migration, remittance and remittance inflow such as (Siddiqui, 2005), (Mahmood, 1991),(Hadi, 1999),(Siddiqui, 2003), (Ratha, 2005), (Ratha, 2007), (Bangladesh Bank, 2012, 2013) etc. However, giving concentration on previous literatures the present study has attempted to find out the trends of remittance flow in Bangladesh through migrants workers based on secondary data. The research article also tries to find out the reasons behind the uneven flows of migration from Bangladesh and remittance inflow from overseas migrants. To conduct this study, data are collected from Bangladesh Bank (BB), Bangladesh Economic Review (BER), Ministry of Expatriate's Welfare and Overseas Employment (MEWOE), Bureau of Manpower, Employment and Training (BMET). Moreover, ii should be necessary to mention that no descriptive statistics has been applied for analyzing this article.

\section{Migration flows from Bangladesh}

Overseas employment and remittances play an important role in the economic development of Bangladesh. A sizeable number of Bangladeshi labor forces are employed in different parts of the world including the Middle East. With a few exceptions, manpower export has been increasing every year. In FY 2007-2008, around 9.81 lakhs Bangladeshi are employed in abroad as a migrant labor where it was only 1.95 lakhs in 2001-2002 (Table 1). However, after the FY 2007-08, the flow of labor migration has been following a declining trend and it is 4.41 lakhs during the FY 2012-2013. It is observed that highest amount of labor are migrated in FY 2007-2008. After FY 2007-2008, there is negative and slow growth of labor migration. The probable reasons for this are multiple. One of the reasons is the stiff competition from new labor-exporting countries like Nepal, Vietnam and Cambodia, which have recently entered the international labor market and supply cheaper labor. Another reason is the rise in unemployment in some Middle East countries due to global economic recession and collapse of the construction sector in the Middle East.

Table 1: Number of Expatriate Bangladeshi

\begin{tabular}{|c|c|c|}
\hline Fiscal Year & No of employment abroad (000) & Percentage Change (\%) \\
\hline $2001-2002$ & 195 & -8.45 \\
\hline $2002-2003$ & 251 & 28.72 \\
\hline $2003-2004$ & 277 & 6.37 \\
\hline $2004-2005$ & 250 & -6.13 \\
\hline $2005-2006$ & 291 & 16.4 \\
\hline $2006-2007$ & 564 & 93 \\
\hline $2007-2008$ & 981 & 73.93 \\
\hline $2008-2009$ & 650 & -33.74 \\
\hline $2009-2010$ & 427 & -34.30 \\
\hline $2010-2011$ & 439 & 2.81 \\
\hline $2011-2012$ & 691 & 57.40 \\
\hline $2012-2013$ & 441 & -36.18 \\
\hline
\end{tabular}

Source: Bangladesh Economic Review 2012 and Bangladesh Bank.

The highest numbers of Bangladeshi workers are migrated to the ten countries such as Saudi Arabia, UAE, Qatar, Oman, Bahrain, Kuwait, Libya, Iraq, Singapore and Malaysia. In case of labor migration Bangladesh is highly dependent on the Middle Eastern countries. Analyzing the data from 2001 to 2012 it reveals that $70 \%$ of total export was in different countries of Middle East. The political unrest in these Middle Eastern countries however might create an adverse effect on migration as well as flow of remittance into the country. Besides, new employment opportunities have also been created for Bangladeshi workers in Bahrain, Qatar, Jordan, Lebanon, South Korea, Brunei, Mauritius, the United Kingdom, Ireland and Italy, Australia, Iraq, Sweden, South Africa, Algeria, Angola (BER ,2012). But it is no more significant compare to the Middle Eastern countries. So, Government of Bangladesh is trying to explore and expand new labor market in Europe and Africa. 
Table 2: No of Expatriate Bangladeshi by Country

\begin{tabular}{|c|c|c|c|c|c|c|c|c|c|}
\hline $\begin{array}{c}\text { Calendar } \\
\text { Year }\end{array}$ & $\begin{array}{c}\text { Saudi } \\
\text { Arabia }\end{array}$ & Kuwait & UAE & Bahrain & Oman & Malaysia & Singapore & Others & Total \\
\hline 2001 & 137248 & 5341 & 16252 & 4371 & 4561 & 4921 & 9615 & 6656 & 188965 \\
\hline 2002 & 163254 & 15767 & 25438 & 5370 & 3927 & 85 & 6870 & 4545 & 225256 \\
\hline 2003 & 162131 & 26772 & 37346 & 7482 & 4029 & 28 & 5304 & 11148 & 254190 \\
\hline 2004 & 139031 & 41108 & 47012 & 9194 & 4435 & 224 & 6948 & 25006 & 272958 \\
\hline 2005 & 80425 & 42029 & 61978 & 10716 & 4827 & 2911 & 9651 & 37903 & 266440 \\
\hline 2006 & 109513 & 35775 & 130204 & 16355 & 8082 & 20469 & 20139 & 44032 & 381516 \\
\hline 2007 & 204112 & 4212 & 226392 & 16433 & 17478 & 273201 & 38324 & 52457 & 832609 \\
\hline 2008 & 132124 & 319 & 419335 & 13182 & 52896 & 131762 & 56581 & 68836 & 875055 \\
\hline 2009 & 14666 & 10 & 258348 & 28462 & 41704 & 12402 & 39581 & 80141 & 475278 \\
\hline 2010 & 7069 & 48 & 203308 & 21842 & 42642 & 919 & 39053 & 75840 & 390702 \\
\hline 2011 & 15030 & 29 & 282734 & 13928 & 135260 & 742 & 48666 & 71673 & 568062 \\
\hline 2012 & 21232 & 2 & 215452 & 21777 & 180326 & 804 & 58657 & 109548 & 607798 \\
\hline
\end{tabular}

Source: Bangladesh Economic Review, 2012.

However, the labor market for Bangladeshi migrants is not static. For example, during the 1970s Saudi Arabia, Iraq, Iran and the Libyan Arab Jamahiriya were some of the major destination countries. While Saudi Arabia has remained the top destination, Malaysia and the UAE also became important receivers (Farid, Mozumdar, Kabir and Hossain, 2009).Due to Asian financial crisis of 1997, the number of Bangladeshi migrants to Malaysia has decreased and the UAE has taken the place (Siddiqui, 2005).During the current decade, there has been a significant change in the structure of the expatriate Bangladeshis by country. In 2001, about 73 percent Bangladeshi workers went to Saudi Arabia and this rate decreased to 3 percent in 2012. On the other hand, in 2001, about 9 percent of the total exported manpower went to the UAE which reached to 35 percent in 2012 . During the same period, the manpower exports in Oman increased fifteen times. In 2001, about 3 percent Bangladeshi workers went to the rest of the world which increased to 18 percent in 2012. It indicates that the overseas labor market is expanding gradually.

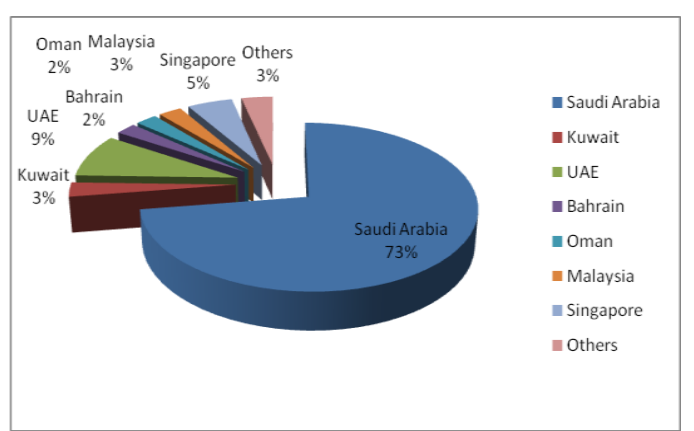

Overseas employment by country in 2001

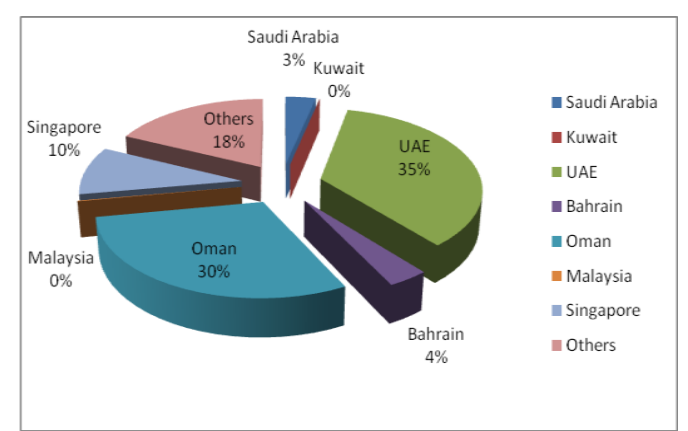

Overseas employment by country in 2012

Source: Authors calculation based on Bangladesh Economic Review data.

Figure: 1 Migration by country in 2001 and 2012

Analyzing the statistics of the BMET, it is observed that about half of the overseas workers who went abroad are less skilled. Less skilled labors have the highest share of the total labor migration than those of skilled and semiskilled and professional labor. In calendar year 2011, the total labor migration was 568062 whereas the lessskilled, skilled and professional labor migration increased by 7.6, 152.9 and 208.0 percent respectively than that of the previous calendar year of 2010. On the other hand, in calendar year 2012 the total labor migration is 607798 whereas the less- skilled labor migration is increased by 22.4 percent but semi-skilled, skilled and professional labor migration is decreased than that of the previous calendar year 2011. It is also observed that the share of professional workers has decreased significantly. However, the rate of migration of the skilled and semi-skilled workers are at the satisfactory in 2012(table 3). 
Table 3: Number of Expatriates Classified by Skill

\begin{tabular}{|c|c|c|c|c|c|}
\hline Calendar Year & Professional & Skilled & Semi-skilled & Less -skilled & Total \\
\hline 2001 & 6940 & 42742 & 30702 & 109581 & 188965 \\
\hline 2002 & 14450 & 56265 & 36025 & 118516 & 225256 \\
\hline 2003 & 15862 & 74530 & 29236 & 136562 & 254190 \\
\hline 2004 & 19107 & 81887 & 24566 & 147398 & 272958 \\
\hline 2005 & 1945 & 116393 & 24546 & 112556 & 255440 \\
\hline 2006 & 925 & 115468 & 33965 & 231158 & 381516 \\
\hline 2007 & 676 & 165338 & 183673 & 482922 & 832609 \\
\hline 2008 & 1864 & 281450 & 132825 & 458916 & 875055 \\
\hline 2009 & 1426 & 134265 & 74604 & 255070 & 475278 \\
\hline 2010 & 387 & 90621 & 12469 & 287225 & 390702 \\
\hline 2011 & 1192 & 229149 & 28729 & 308992 & 568062 \\
\hline 2012 & 812 & 209368 & 20498 & 377120 & 607798 \\
\hline
\end{tabular}

Source: Bureau of Manpower, Employment and Training.

There is a significant change in the structure of expatriates classified by skill during the last few years. In 2001 the share of professional expatriates was 4 percent of total manpower export, which in the subsequent year gradually come down. The share of less skilled workers was gradually increasing in the subsequent year. In calendar year 2001, share of less skilled workers was 58 percent whereas in 2012 the share is 62 percent. In calendar year 2012, out of 607798 labor migrations 62 percent were less-skilled, 3 percent were semi-skilled, 35 percent were skilled and only 0.13 percent were professionals while the share of less-skilled, skilled and semiskilled labor and professional labor migration were 54, 40, 5 and .21 percent respectively in the previous calendar year of 2011. Due to the crisis in Middle Eastern countries and decline in the demand of labor from Bangladesh to Malaysia, Saudi-Arabia, Kuwait and Singapore, there is slower growth of less-skilled and semiskilled labors migration Although the share of skilled labor of the total labor migration has increased compared to the less-skilled one, it may decline in the upcoming calendar years if the government does not take necessary measures.

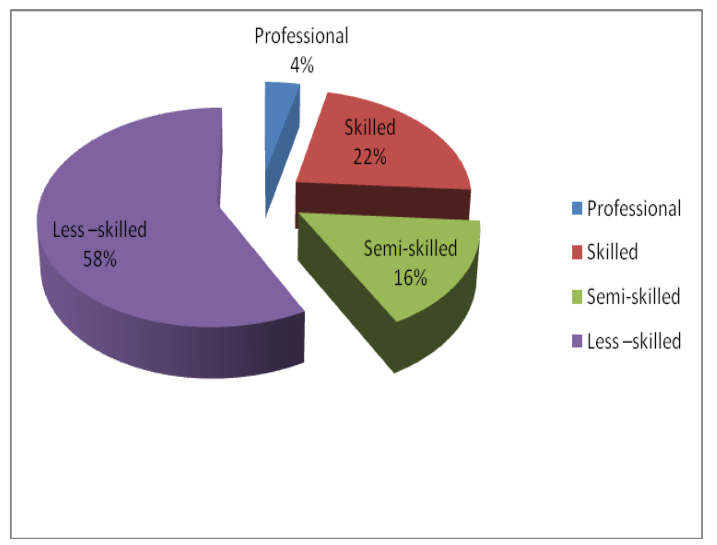

Overseas employment by profession in 2001

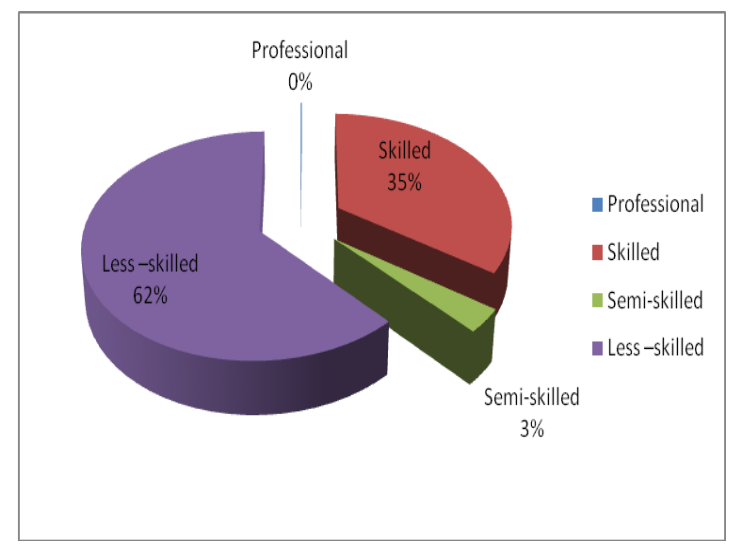

Overseas employment by profession in 2012

Source: Authors calculation based on Bureau of Manpower,Employment and Training data.

Figure: 2 overseas employments by professions in 2001 and 2012

\section{Flow of remittance to Bangladesh}

Like overseas employment, over the years, the flow of remittance in Bangladesh is increasing in volume, but there is a slower growth of remittance since FY 2007-08. This is due to rise in unemployment in some Middle East due to global economic recession and collapse of the construction sector in the Middle East. Another reason is political unrest in these Middle Eastern countries however might create an adverse effect on migration as well as flow of remittance into the country .Remittance sent by overseas workers have increased from US\$ 2505.44 million in FY 2001- 2002 to US\$ 14461.15 million in FY 2012-2013 (Bangladesh Bank, 2013). Remittance during 2012-2013 is US\$ 12843.43 million which is more than 12.60 percent that of the last year (Table 4). One of the reasons of this growth is that Bangladesh Bank has simplified the drawing arrangements between foreign exchange house and domestic banks. On the other hand, Bangladesh Bank has given permission to 39 banks for establishing more than 1000 drawing arrangements with 262 exchange houses 
all over the world for collecting remittance (Bangladesh Bank, 2012). Some banks have already established 25 exchange houses/ subsidiaries abroad to collect remittance. Another reason for remittance growth is Bangladesh Bank has given instructions to the commercial banks to ensure delivery of remittance to the beneficiary within 72 hours as per existing policy. Several banks are now allowed to distribute remittance using the countrywide outlets of mobile operators like Grameenphone, Banglalink \& Robi (Bangladesh Bank, 2012).

Table 4: Recent Flow of Remittance to Bangladesh

\begin{tabular}{|c|c|c|}
\hline Fiscal Year & Million US\$ & Percentage change (\%) \\
\hline $2001-2002$ & 2501.44 & 32.81 \\
\hline $2002-2003$ & 3060.31 & 22.25 \\
\hline $2003-2004$ & 3372.49 & 10.20 \\
\hline $2004-2005$ & 3848.30 & 14.11 \\
\hline $2005-2006$ & 4801.88 & 24.78 \\
\hline $2006-2007$ & 5978.47 & 24.50 \\
\hline $2007-2008$ & 7914.78 & 32.39 \\
\hline $2008-2009$ & 9689.16 & 22.42 \\
\hline $2009-2010$ & 10987.40 & 14.40 \\
\hline $2010-2011$ & 11650.32 & 6.0 \\
\hline $2011-2012$ & 12843.43 & 10.24 \\
\hline $2012-2013$ & 14461.15 & 12.60 \\
\hline
\end{tabular}

Source: Bureau of Manpower, Employment \& Training and Bangladesh Bank.

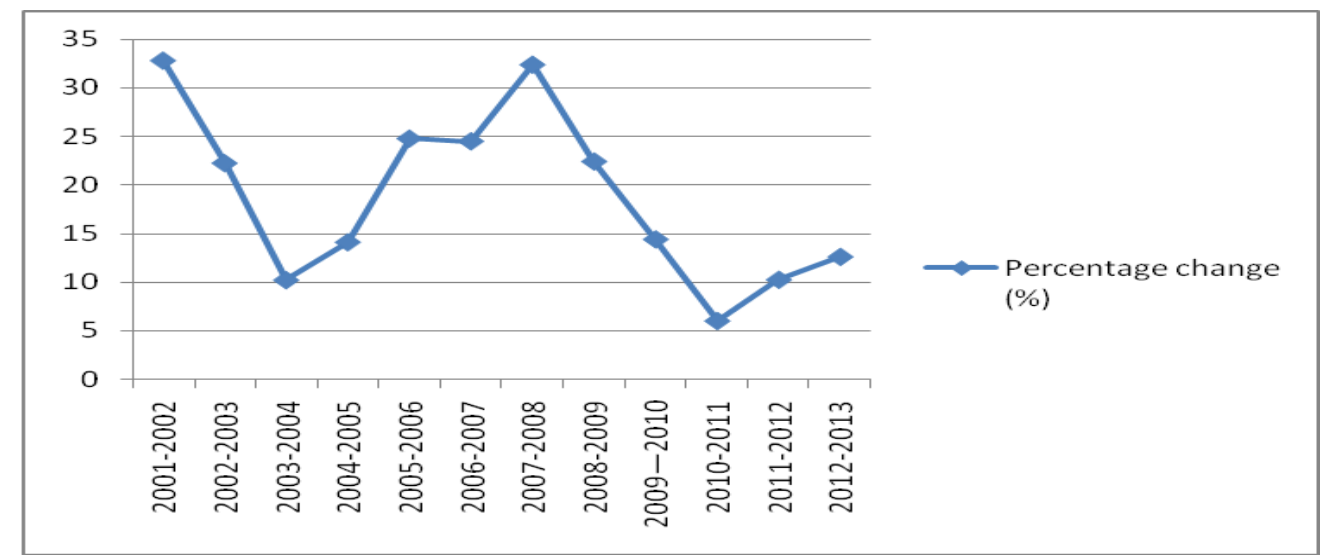

Source: Authors calculation based on Bureau of Manpower,Employment and Training data.

Figure 3: Percentage change of remittance inflow over the year

The share of remittance to GDP and export earning has been increasing over the year. In fiscal year 2011-2012 the remittance as a percentage of GDP is 11.11 but in 2001-2002 it was 5.26 which is 5.85 percent more than that of year 2001-2002. In fiscal year 2011-2012 the remittance as a percentage of export earning is 52.92 which was 11.14 percent higher than that of the year 2001-2002. Therefore, remittance contribute our economy by boosting up exports and the country's balance of payment.

Table 5: Remittance as a Percentage of GDP and Export Earnings

\begin{tabular}{|c|c|c|}
\hline Fiscal Year & As a percentage of GDP & As a percentage of export \\
\hline $2001-2002$ & 5.26 & 41.78 \\
\hline $2002-2003$ & 5.90 & 46.76 \\
\hline $2003-2004$ & 5.98 & 44.35 \\
\hline $2004-2005$ & 6.37 & 44.47 \\
\hline $2005-2006$ & 7.75 & 49.62 \\
\hline $2006-2007$ & 8.83 & 56.09 \\
\hline $2007-2008$ & 10.02 & 62.25 \\
\hline $2008-2009$ & 10.96 & 67.80 \\
\hline $2009-2010$ & 11.13 & 50.82 \\
\hline $2010-2011$ & 10.53 & 52.92 \\
\hline
\end{tabular}

Source: Bangladesh Economic Review, 2012.

It is evident from the figure 4 that despite significant decline the share of remittance, the highest amount of remittance is still coming from Saudi Arabia. In FY 2001, about 45.90 percent of the total remittance was 
received from Saudi Arabia which declined to 28.69 percent in FY 2011-12( Fig 4).On the other hand, the share of remittance of UAE in FY 2011-12 is 18.72 percent which was 9.3 percent in FY 2001-2002(Fig 4). Most of the countries of the Middle East regions seen downward trends of the remittance in the recent past. This is because of global economic recession and political unrest of Middle East in the recent year. Another reason is Government of different Middle Eastern countries stop manpower import from Bangladesh due to unfair practice and dishonesty of recruiting agency. It is also observed that the remittance from the non Middle East countries like USA, UK, Malaysia, Singapore etc, grew significantly in the last couple of year.

Table 6: Country Wise Remittances

\begin{tabular}{|c|c|c|c|c|c|c|c|c|c|c|c|c|}
\hline $\begin{array}{l}\text { Fiscal } \\
\text { year }\end{array}$ & $\begin{array}{l}\text { Saudi } \\
\text { Arabia }\end{array}$ & UAE & Qatar & $\begin{array}{l}\text { Oma } \\
\mathrm{n}\end{array}$ & $\begin{array}{l}\text { Bahrai } \\
\text { n }\end{array}$ & Kuwait & USA & UK & $\begin{array}{l}\text { Malaysi } \\
\text { a }\end{array}$ & $\begin{array}{l}\text { Singap } \\
\text { ore }\end{array}$ & others & Total \\
\hline $2001-2002$ & 1147.95 & 233.49 & 90.60 & $\begin{array}{l}103.2 \\
7 \\
\end{array}$ & 54.12 & 285.75 & 356.24 & 103.31 & 46.85 & 14.26 & 65.29 & 2501.13 \\
\hline $2002-2003$ & 1254.31 & 327.40 & 113.55 & $\begin{array}{l}114.0 \\
6\end{array}$ & 63.72 & 338.59 & 458.05 & 220.22 & 41.40 & 31.06 & 99.61 & 3061.97 \\
\hline $2003-2004$ & 1386.03 & 373.46 & 113.94 & $\begin{array}{l}118.5 \\
3 \\
\end{array}$ & 61.11 & 361.24 & 467.81 & 297.54 & 37.06 & 32.37 & $\begin{array}{l}123.1 \\
8 \\
\end{array}$ & 3372.27 \\
\hline $2004-2005$ & 1510.45 & 442.24 & 136.41 & $\begin{array}{l}131.3 \\
2 \\
\end{array}$ & 67.18 & 406.80 & 557.31 & 375.77 & 25.51 & 47.69 & $\begin{array}{l}147.6 \\
0\end{array}$ & 3848.29 \\
\hline $2005-2006$ & 1696.96 & 561.44 & 175.64 & $\begin{array}{l}165.2 \\
5 \\
\end{array}$ & 67.33 & 494.39 & 760.69 & 555.71 & 20.81 & 684.84 & $\begin{array}{l}238.8 \\
1 \\
\end{array}$ & 4801.88 \\
\hline 2006-2007 & 1734.70 & 804.84 & 233.17 & $\begin{array}{l}196.4 \\
7 \\
\end{array}$ & 79.96 & 680.70 & 930.33 & 886.90 & 11.84 & 80.24 & $\begin{array}{l}339.3 \\
2 \\
\end{array}$ & 5978.47 \\
\hline $2007-2008$ & 2324.23 & $\begin{array}{l}1135.1 \\
4\end{array}$ & 289.79 & $\begin{array}{l}220.6 \\
4\end{array}$ & 138.20 & 863.73 & 1380.08 & 896.13 & 92.44 & 130.11 & $\begin{array}{l}444.3 \\
8 \\
\end{array}$ & 7914.78 \\
\hline $2008-2009$ & 2859.09 & $\begin{array}{l}1754.9 \\
2 \\
\end{array}$ & 343.36 & $\begin{array}{l}290.0 \\
6 \\
\end{array}$ & 157.45 & 970.75 & 1575.22 & 789.65 & 282.20 & 165.13 & $\begin{array}{l}501.3 \\
3 \\
\end{array}$ & 9689.16 \\
\hline $2009-2010$ & 3427.10 & $\begin{array}{l}1890.3 \\
0 \\
\end{array}$ & $\begin{array}{l}1019.1 \\
8 \\
\end{array}$ & $\begin{array}{l}170.1 \\
4 \\
\end{array}$ & 193.46 & 587.09 & 349.09 & 360.91 & 827.51 & $\begin{array}{l}1451.8 \\
9\end{array}$ & $\begin{array}{l}453.8 \\
6 \\
\end{array}$ & $\begin{array}{l}10987.4 \\
0\end{array}$ \\
\hline $2010-2011$ & 3290.03 & $\begin{array}{l}2002.6 \\
3\end{array}$ & 319.35 & $\begin{array}{l}334.3 \\
2\end{array}$ & 185.92 & 1075.75 & 1848.52 & 889.60 & 703.73 & 202.32 & $\begin{array}{l}789.1 \\
4\end{array}$ & $\begin{array}{l}11650.3 \\
1\end{array}$ \\
\hline 2011-2012 & 3684.37 & $\begin{array}{l}2404.7 \\
8 \\
\end{array}$ & 335.25 & $\begin{array}{l}400.9 \\
3 \\
\end{array}$ & 298.48 & 1190.13 & 1498.45 & 987.45 & 847.49 & 311.47 & $\begin{array}{l}884.6 \\
1 \\
\end{array}$ & 12843.4 \\
\hline
\end{tabular}

Source: Bangladesh bank, 2012.

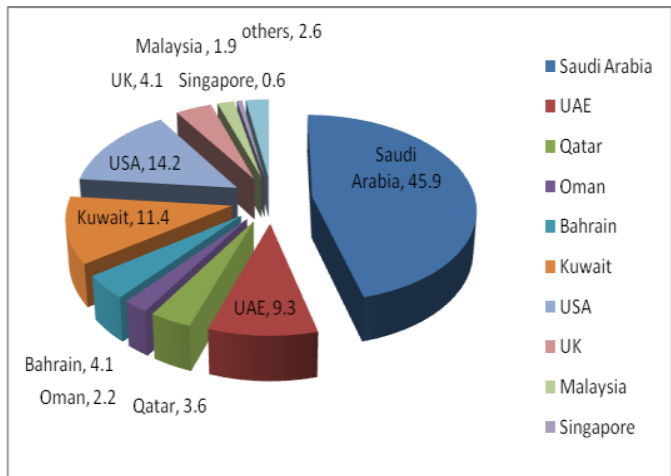

Country-wise remittance in 2001

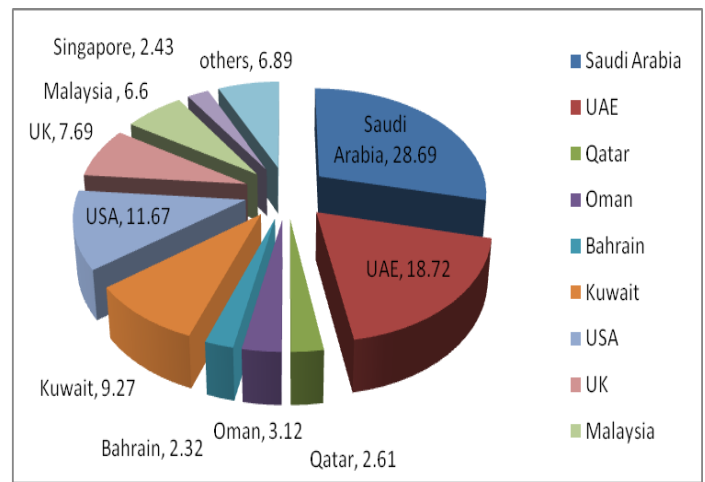

Country- wise remittance in 2012

Source: Authors calculation based on Bangladesh Bank data.

Figure 4: Comparative scenario of country- wise remittance inflow between 2001-02 and 20112012

Figure 5 shows the annual growth rate of remittance and migration from the FY 2001-2002 to 2012-2013 which is calculated as per percentage change of the previous year. Both the growth rates show fluctuating trend over the years, but the rate of fluctuation is very much high for growth rate of migration than that of remittances .It is also observed that sometimes migration growth is negative but growth rate of remittance is always positive. After FY 2007-2008, there is a declining trend of migration and remittance growth with few exceptions (Fig 5). In some cases there is a huge gap of migration and remittance growth. For instance, In FY 2006-2007 migration growth is 93 percent but remittance growth is 24.78 percent (Fig 5). The main reason for the gap between the number of migrants and remittance flows is that Bangladesh has exported more unskilled and semi-skilled migrants, whose wages are rather low compared to those of skilled and professional workers (Siddiqui and Abrar, 2001). On the other hand, in FY 2012-2013 manpower export is reduced but there is a positive growth of remittance. One of the reasons for increasing trend of remittance is that some skilled manpower is exported to 
abroad. Another reason is that people use formal channel for remittance transmission. Government has taken several steps for quick transmission of remittance trough formal channel. Such as i) approval mechanism of drawing arrangement of Bangladeshi bank with the foreign exchange house is simplified. By this time 300 foreign exchange houses have made 850 drawing arrangement with 42 Bangladeshi Bank (BER, 2013). ii) In this time 16 local banks are allowed to establish 44 exchange houses for collecting remittance and transmission to the countries (BER, 2013).iii) Bangladesh Bank has given approval to 4 banks to distribute remittance through outlet of Mobile phone operator (BER, 2013).

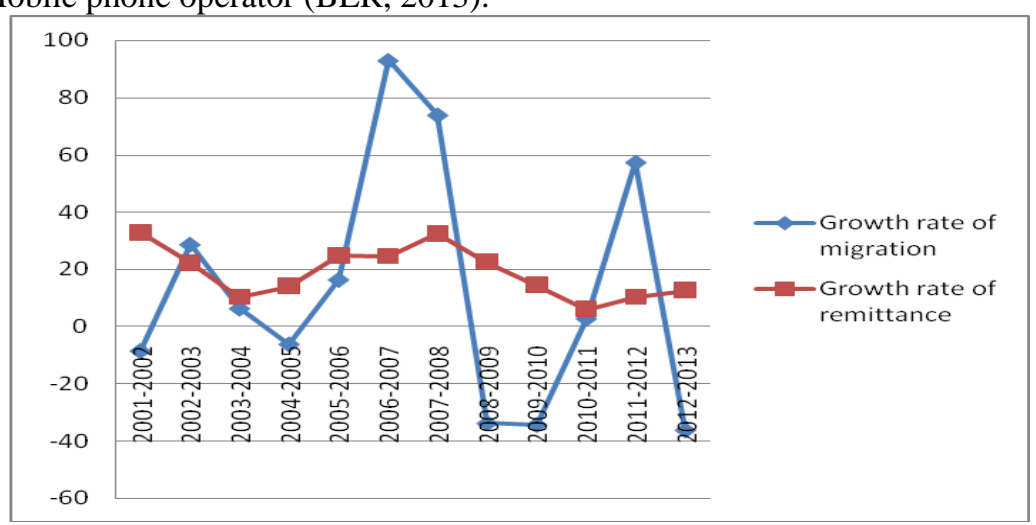

Source: Authors calculation based on Bangladesh Bank data.

Figure: 5 Growth rates of remittances and migration over the years.

\section{Conclusion}

As Bangladesh is a hugely labor surplus country and it is not possible for government to create employment opportunities for all of its manpower. It would the best possible option for these Bangladeshi migrants. On the other hand, remittance is now constitute the single largest source of foreign exchange earnings and play a crucial role in alleviating the foreign exchange constraints of Bangladesh. This paper has attempted to capture different aspects of voluntary migration from Bangladesh as well as international remittance inflow to Bangladesh on the basis of available secondary data. With few exceptions, manpower export and remittances increase every year. In FY 2007-2008, highest amount of labor are migrated but after FY 2007-2008 there is a negative and slower growth of labor migration. It is also observed that in case of labor migration, Bangladesh is highly dependent on Middle East countries. Although, manpower export to Saudi Arabia which was the largest labor market for us is decreasing. One of the reasons behind this is world financial crisis. Another reason is Government of Saudi Arabia stop manpower import from Bangladesh due to unfair practices and dishonesty of recruiting agencies. This paper also identifies that Bangladesh export mainly unskilled and semiskilled employees. The rate of migration of the skilled workers is also at the satisfactory level. This is due to Govt has taken few initiatives to increase skilled manpower exports. Such as, establishment of Institute of marine technology and technical training center for training of potential migrants. It is also observed that Bangladesh also export few professional employees but in the recent past it is decreasing. Government should take initiatives to increase professional manpower exports which are more paid than other categories of manpower. On the other hand, over the years the flow of remittance is increasing in volume but there is a slower growth of remittance since FY 2007-2008. Although the labor migration to Saudi is decreasing but the highest amount of remittance is still coming from Saudi Arabia. Since labor migration to Middle East is decreasing, government should search for new market for manpower export and should take bilateral agreement with European countries to export manpower. It is also the responsibility of government to reduce the influence of recruiting agencies and to take initiatives to export manpower.

\section{References:}

[1]. Bangladesh Bank. The Central Bank of Bangladesh, Government of the People's Republic of Bangladesh, Dhaka. 2011. (From http://www.bangladesh-bank.org).

[2]. Bangladesh Bank.). The Central Bank of Bangladesh, Government of the People's Republic of Bangladesh, Dhaka, 2012. (From http://www.bangladesh-bank.org).

[3]. Bangladesh Bank. The Central Bank of Bangladesh, Government of the People's Republic of Bangladesh, Dhaka, 2013.From http://www.bangladesh-bank.org).

[4]. Bangladesh Economic Review.. Economic Advisor Wing, Finance Division, Ministry of Finance, Government of the People's Republic of Bangladesh, Dhaka,2011.

[5]. Bangladesh Economic Review. Economic Advisor Wing, Finance Division, Ministry of Finance, Government of the People's Republic of Bangladesh, Dhaka, 2012.

[6]. Bangladesh Economic Review.. Economic Advisor Wing, Finance Division, Ministry of Finance, Government of the People's Republic of Bangladesh, Dhaka, 2013.(accessed from http://www.mof.gov.bd/en/budget/09_10/ber/bn/07.\%20Chapter3\%20_Bangla-9_.pdf). 
[7]. Bureau of Manpower Employment and Training. Government of the Peoples' Republic of Bangladesh, Dhaka, 2012. (From http://www.bmet.org.bd).

[8]. Farid. K. S, Mozumdar. L, Kabir. M.S and Hossain. K. B. Trends in international migration and remittance flows: Case of Bangladesh" Journal of Bangladesh Agriculture University. 7(2), 2009, 387-394.

[9]. Hadi. A. Overseas Migration and the Well-being of Those Left Behind in Rural Communities of Bangladesh. Asia-Pacific Population Journal, 14(1), 1999, 43-58.

[10]. Mahmood. R. A. International Migration, Remittances and Development: Untapped Potentials for Bangladesh, Bangladesh Institute of International Strategic Studies Journal, 12(4), 1991.

[11]. Mannan. M.A. Bangladeshi Migrants in Saudi Labor Market: An Empirical Analysis, RMMRU, Dhaka. 2001.

[12]. Ratha, D .Worker's Remittances: An Important and Stable Source of External Development Finace," Chapter 1 in S. M. Mainbo aled D. Ratha (eds.)"Remittances - Development Impact and Future Prospects. The World Bank. 2005

[13]. Ratha, D: Leveraging Remittances for Development. Policy Brief, June. Migration Policy Institute. Washington D.C, 2007.

[14]. Siddiqui, T. Transcending Boundaries: Labor Migration of Women from Bangladesh, University Press Limited, Dhaka, 2001.

[15]. Siddiqui, T. Migration as a Livelihood Strategy of the Poor: The Bangladesh case, Paper presented at the DFID-RMMRU Regional Conference on Migration, Development and Pro-poor Policy Choices in Asia, held in Dhaka, 22-24 June, 2003.

[16]. Siddiqui, T. International Labour Migration from Bangladesh: A descent work perspective. Working Paper No.66, Policy Integration Department, National Policy Group, International Labour Office, Geneva, 2005.

[17]. Siddiqui, T. and Abrar, C.R. Migrant Workers' Remittances and Micro-finance Institutions, International Labor Organization (mimeo), Geneva, 2001

[18]. Tigno, J.V. Trans-national Labour Migration: Issues, Trends and Strategies for East Asian Community Building, Paper presented at the International Conference on Across the Border Issues, from 30-31 March, 2006 organized by Academy of East Asian studies, Sungkyunkwan University, Seoul,2006.

[19]. Zeitlyn, B. Migration from Bangladesh to Italy and Spain. Refugee and Migratory Movements Research Unit, Dhaka, 2006. 